\title{
Avaliação in vitro da Atividade Antioxidante do Extrato Hidroetanólico e de suas Frações Obtido das Folhas de Psydium guajava l. (Myrtaceae)
}

William Gustavo de Lima*, Alexandra Rodrigues Alves, Luciana Alves

Rodrigues dos Santos Lima

${ }^{1}$ Universidade Federal de São João Del-Rei, Divinópolis/MG

*e-mail: williamgustavofarmacia@hotmail.com

\section{Resumo}

Os radicais livres gerados na respiração aeróbica estão relacionados a uma grande variedade de patologias, dentre as quais o desenvolvimento de carcinomas, lesões hepáticas e ao envelhecimento dérmico. Neste contexto se destaca o estudo de constituintes fitoquímicos, como potenciais agentes antioxidantes, que neutralizam e quebram a etapa de propagação das reações radicalares. Este trabalho objetiva avaliar a atividade antioxidante in vitro do extrato hidroetanólico e de suas frações hexânica, diclorometânica e acetato de etila obtidos das folhas da Psydium guajava L. (Myrtaceae). 35,82 g de folhas de goiabeira foram coletadas na cidade de Divinópolis/MG (herbário $\mathrm{n}^{\circ}$ 43209), rasuradas e secadas em estufa a $40{ }^{0} \mathrm{C}$ por 7 dias. Posteriormente $3,34 \mathrm{~g}$ das folhas secas foram maceradas em solução hidroetanólica a $70 \%$ por 7 dias, e o extrato foi concentrado no rotavapor. $\mathrm{O}$ extrato bruto foi fracionado pelo método de partição utilizando hexano, diclorometano e acetato de etila. $\mathrm{O}$ extrato bruto e as frações obtidas foram avaliadas quanto a atividade antioxidante utilizando o método do DPPH (2,2-difenil-1-picril-hidrazil). As folhas da goiabeira apresentaram teor de umidade de 59,69\%. O rendimento do extrato bruto obtido pelo método de maceração foi de 7,18\%, e as frações hexânica, diclorometânica e acetato de etila possuíram rendimento de 6,25\%, 12,5\% e 16,66\%, respectivamente. A inibição do radical de DPPH, que se correlaciona com a atividade antioxidante do material, variou de $72,22 \%$ á $98,05 \%$, possuindo o extrato hexânico a maior porcentagem de inibição in vitro. Estes resultados mostram que o extrato hidroetanólico e suas frações possuíram significativa atividade antioxidante, o que justifica a utilização das folhas da goiabeira como 
uma medida profilática para as alterações fisiopatológicas características da ação destes radicais livres altamente reativos.

Palavras-chave: Psydium guajava L. (Myrtaceae), Extrato Hidroetanólico, Atividade antioxidante. 